\title{
EFFECTS OF MULBERRY HEARTWOOD EXTRACT ON GENES RELATED TO LIPID METABOLISM
}

\author{
Milena Pasheva, Milka Nashar, Oskan Tasinov, Diana Ivanova \\ Department of Biochemistry, Molecular Medicine and Nutrigenomics, \\ Medical University of Varna, Bulgaria
}

\begin{abstract}
Scientific evidence exists that extracts from different parts of Morus nigra (mulberry tree), mainly fruits, leaves and root bark, exhibit various beneficial effects, such as antiviral, antihyperglycemic, antiatherogenic and hypotensive activity. Although it is known that the heartwood has a specific phytochemical composition, the biological effects of this part of the plant are not yet clarified. This study examines the effect of $40 \%$ ethanol infusion from mulberry heartwood on the expression of three genes related to lipid metabolism: CCAAT/enhancer binding protein-alpha $(\mathrm{C} / \mathrm{EBPa})$ gene, adipogenic transcriptional factors peroxisome proliferator-activated receptor gamma (PPAR $\gamma)$ and fatty acid-binding protein (aP2) genes in adipocytes. Results obtained present that treatment with two concentrations of mulberry ethanol extract decreased expression of aP2 messenger RNA as compared to controls. Based on these results we concluded that heartwood mulberry extract had beneficial effects on lipid metabolism and could be a potential source for search of active compounds for treatment of metabolic disorders related to adipose tissue metabolism.
\end{abstract}

Keywords: Morus nigra, heartwood extract, adipocytes, gene expression, lipid metabolism

\section{INTRODUCTION}

In the last few decades medicinal plants are on the focus of scientific studies as potential sources of new active compounds with beneficial biological effects. Scientific hypothesis often generate from the folk knowledge about the usage of the plants. Morus nigra L. (mulberry tree) is traditionally applied by the folk medicine for various complaints. According to some authors extracts from mulberry leaves exhib-

Address for correspondence:

Milena Gincheva Pasheva,

Department of Biochemistry, Molecular Medicine and

Nutrigenomics

Medical University of Varna

55 M. Drinov Str.

9002 Varna, Bulgaria

e-mail: pasheva19@gmail.com

Received: April 27, 2015

Accepted: May 19, 2015 it diuretic, hypoglycemic, and hypotensive activities, whereas the fruits and root bark are known to possess antiinflammatory, antitussive, and antipyretic properties $(5,20,30,33)$. Along with the knowledge about the medicinal properties of the plant, mulberry is known to have also other traditional applications its heartwood is used as a material for barrels manufactured for storage of alcoholic beverages and respectively for their aging. Although, the ethanol extracts of mulberry heartwood have specific phytochemical composition (8), to our knowledge their biological effects still remain unrevealed.

Several studies report that extracts from mulberry leaves and fruits have a potential to reduce significantly blood cholesterol, triglycerides, VLDL and LDL levels $(1,25,34)$. These reports allow us to suggest that the mulberry tree could be potentially considered as a source of remedies for treatment of obesity and diabetes. 
Milena Pasheva, Milka Nashar, Oskan Tasinov et al.

Obesity is associated with adipocyte differentiation and fat accumulation (16). The molecular basis of adipocyte differentiation is a subtle coordinated work of the adipogenic transcriptional factors such as CCAAT/enhancer binding protein-alpha (C/ $\mathrm{EBPa}$ ) and nuclear receptor peroxisome proliferatoractivated receptor gamma (PPAR $\gamma$ ). They play a key role for the expression of adipocyte-specific genes, such as adipocyte fatty acid-binding protein (aP2) which is one of the genes involved in lipid accumulation into the cells (7). The two transcriptional factors alone or in cooperation regulate the expression of genes for synthesis of enzymes involved in triacylglycerol synthesis, glucose transporters, acylCoA synthases (ACSs) and the fatty acid binding proteins (FABPs) family. The adipocyte cytosolic aP2, which is a member of FABPs, binds with high affinity to hydrophobic ligands such as saturated and unsaturated long-chain fatty acids and eicosanoids such as hydroxyeicosatetraenoic acid, leukotrienes and prostaglandins $2(3,13,19)$.

The aim of this study was to determine the ability of $M$. nigra (MN) heartwood ethanol extract to modulate the expression of genes involved in lipid metabolism such as C/EBPa, PPAR $\gamma$ and aP2 in a differentiated 3T3-L1 cell line.

\section{MATERIALS AND METHODS}

Heartwood processing and extract preparation

Heartwood samples were subjected to fumigation following the popular technology for aging of beverages: the wooden chips were boiled for $10 \mathrm{~min}-$ utes and then saturated with cold water for 24 hours. Finally, the material was dried for 15 minutes at 150$190^{\circ} \mathrm{C}$. Ethanol infusion from Morus nigra heartwood was prepared following the traditional recipe for coloring high alcoholic beverages: $2 \mathrm{~g}$ dried material from heartwood was placed in 1L 40\% ethanol for 40 days.

\section{Cell culture differentiation and treatment}

Mouse 3T3-L1 preadipocytes were cultured in Dulbecco's modified Eagle's medium (DMEM, Lonza), supplemented with $10 \%$ fetal bovine serum (FBS) and penicillin/streptomycin mixture to final concentration of $100 \mathrm{U} / \mathrm{ml}$ each at $37^{\circ} \mathrm{C}$ in a humidified chamber containing $5 \% \mathrm{CO}_{2}$. Two days after reaching $80 \%$ confluence (designated as day 0 ), cell differentiation was stimulated with differentiating medi- um (DM) containing 10\% FBS and a mixture of 5 $\mu \mathrm{g} / \mathrm{mL}$ insulin/0,5 mM 3-isobutyl-1-methylxanthine (IBMX)/0,25 $\mu \mathrm{M}$ dexamethasone (AppliChem, Biochemica, Germany) for 4 days (day 1 to day 4). After 4 days, the medium was replaced with post DM, containing 10\% FBS and $5 \mu \mathrm{g} / \mathrm{mL}$ insulin for 4 days (day 5 to day 8). At day 8 cells were incubated for 16 hours with MN heartwood ethanol extract at final concentration in the medium of 0.5 or $1 \%$ (groups $0.5 \mathrm{MN}$ and $1 \mathrm{MN}$ respectively). At the end of the experiment cells were collected for RNA extraction.

\section{Quantitative real-time PCR analysis}

Total RNA was extracted from differentiated 3T3-L1 cells using TRI Reagent according to the manufacturer's protocol (Ambion). Complementary DNA was synthesized using Revertaid ${ }^{\mathrm{TM}}$ First Strand Synthesis Kit with oligo $(\mathrm{dT})_{18}$ primers and RevertAid $^{\mathrm{mm}}$ reverse transcriptase (Fermentas). The synthesis reaction was performed on GeneAmp PCR System 9700 (Applied Biosystems). Reaction conditions in final volumes of $10 \mu \mathrm{L}$ were provided according to the manufacturer's guidelines. After synthesis each sample of cDNA was dissolved in $30 \mu \mathrm{L}$ TE-buffer ( $\mathrm{pH}$ 8.0) (AppliChem, Biochemica, Germany). Two-step real-time PCR analysis was performed (ABI PRISM 7500, Applied Biosystems) to estimmate the gene expression level in cultured cells. Maxima SYBR Green qPCR Kit (Fermentas) was used for sample analysis. The cDNA was amplified using forward and reverse primers of target genes (Table 1) commercially synthesized (Invitrogen Alpha DNA, Canada). Beta-actin was used as endogenous control. Amplification products were examined for nonspecific amplification by including an additional denaturation step in the real-time thermal cycler protocol. All measurements were performed at least in triplicate. Gene expression levels were calculated by $2^{-\Delta \Delta \mathrm{Ct}}$ method (24) and expressed as relative units (RU) mRNA compared to the untreated controls where the level of gene expression of interest was considered to be equal to 1.

\section{Statistical Analysis}

Data are presented as mean \pm standard error of mean (SEM). Differences between means of groups were analyzed using Student's $t$-test or one-way ANOVA with Dunnett's multiple comparison test 
Effects of mulberry heartwood extract on genes related to lipid metabolism

Table 1. Sequences of primers used for RT-PCR analysis

\begin{tabular}{|c|c|}
\hline Genes & Nucleotide sequence \\
\hline$\beta$-Actin & $\begin{array}{l}\text { F: 5’-ACG GCC AGG TCA TCA CTA TTG-3' } \\
\text { R: 5'-CAA GAA GGA AGG CTG GAA AAG- 3' }\end{array}$ \\
\hline $\mathrm{C} / \mathrm{EBPa}$ & $\begin{array}{l}\text { F: 5'-AGC AAC GAG TAC CGG GTA CG-3' } \\
\text { R: 5'-TGT TTG GCT TTA TCT CGG CTC-3' }\end{array}$ \\
\hline $\mathrm{aP} 2$ & $\begin{array}{l}\text { F: 5'-AGT GAA AAC TTC GAT GAT TAC ATG AA-3' } \\
\text { R: 5'-GCC TGC CAC TTT CCT TGT G-3' }\end{array}$ \\
\hline $\operatorname{PPAR} \gamma$ & $\begin{array}{l}\text { F: 5'-AAA AAC CCT TGC ATC CTT CAC AAG CAT-3' } \\
\text { R: 5'-TCA ATC GGA TGG TTC TTC GG-3' }\end{array}$ \\
\hline
\end{tabular}

(GraphPad Prism 5.0). Values of $\mathrm{P}<0.05$ were considered to be statistically significant.

\section{RESULTS}

The effects of MN heartwood extract on three genes involved in lipogenesis are summarized in figure 1. Compared to controls, the transcription of $\mathrm{C} / \mathrm{EBPa}$ and aP2 genes was significantly inhibited upon treatment with the extract in both concentrations. Significant decrease of PPAR $\gamma$ levels was estimated only in the cells treated with the lower concentration $(0.5 \%)$ of $\mathrm{MN}$ extract. Variations in the effects of the two applied concentrations were estimated for C/EBPa and PPAR $\gamma$. The mRNA levels of these genes were significantly lower in cells incubated in $0.5 \%$ final concentration of $\mathrm{MN}$ heartwood extract $(0.5 \mathrm{MN})$ as compared with $1 \mathrm{MN}$ treated cells. On

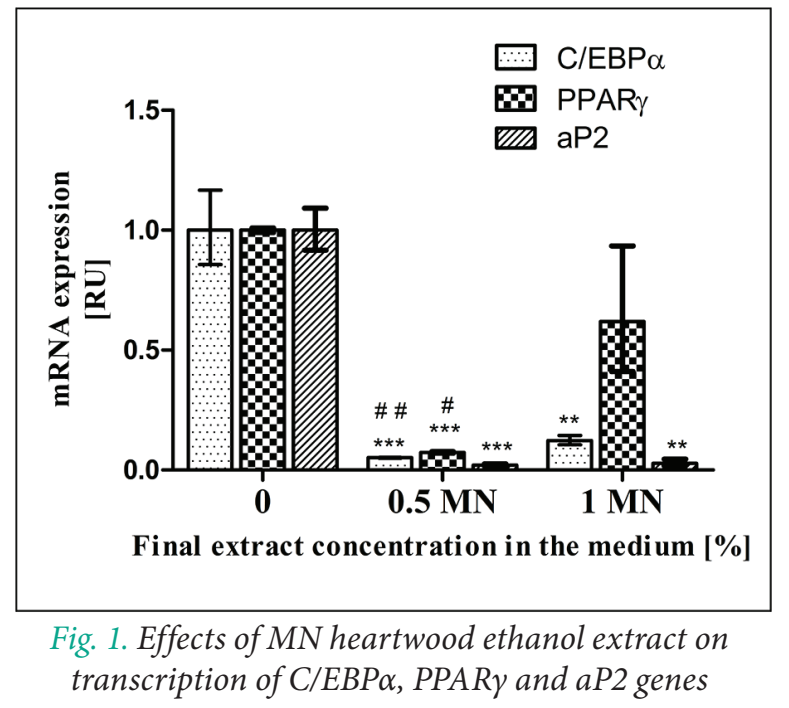

the other hand both concentrations of $\mathrm{MN}$ extract equally inhibited aP2 mRNA expression.

\section{DISCUSSION}

In this study we investigated the effects of $\mathrm{MN}$ heartwood ethanol extract on the expression of three genes directly involved in adipocyte differentiation and lipid accumulation: PPAR $\gamma$ and $\mathrm{C} / \mathrm{EBPa}$ are transcriptional factors that are known to influence the development of fat cells, activating the expression of genes that characterize the adipocyte phenotype, such as aP2 (31). These genes are notably active during the last stages of the differentiation when morphological changes in the cell shape it and accumulation of lipids occurs. In our study the differentiation of the cells to mature adipocytes was verified by observation of lipid droplets accumulation in cytoplasm, followed by Oil Red O staining of triacylglycerols (2) (data are not presented). After differentiation the cells were treated with two concentrations of the extract which were selected based on the cytotoxicity test performed previously (27).

Our results indicate that mRNA expression of $\mathrm{C} / \mathrm{EBP} \alpha$ and $\mathrm{aP} 2$ genes was significantly reduced by the two applied concentrations as compared to controls, whereas PPAR $\gamma$ expression was down regulated by the lower concentration only (fig. 1). Even though this is the first report about the effects of mulberry tree heartwood extracts on lipid metabolism, these results are not surprising. Several studies demonstrated the potential of plant-derived compound or of total extracts to suppress adipogenesis in 3T3-L1 cells $(6,9,10,16,21,32)$. Authors reported that polyphenols, phenolic acids and alkaloids added to the nu- 
Milena Pasheva, Milka Nashar, Oskan Tasinov et al.

tritional medium significantly reduced mRNA expression of PPAR $\gamma$ and $\mathrm{C} / \mathrm{EBP} \alpha$ thus inhibiting cell differentiation and lipid accumulation. The inhibition of aP2 gene expression is associated with lower triacylglycerol accumulation in mature fat cells (32). These effects are verified in vivo in experimental animals $(14,32,35)$. Some authors reported that leaves and fruits extracts of mulberry species have hypolipidemic effects probably due to the active components rich content $(4,22,25)$.

Mulberry species are rich in polyphenols and it is known that different parts of the tree, especially steams, roots and heartwood, have their specific polyphenol composition $(8,11,15,36)$. Recently we estimated highest total polyphenol content of mulberry heartwood ethanol extract, compared with other arboreal species (28). Results obtained in numerous studies, including human intervention studies, associate polyphenol rich diets with improved lipid and cardiovascular profiles as well as increased total plasma antioxidant capacity $(9,12,17,23,25,26)$. Based on this knowledge and on the results presented above it could be suggested that polyphenols modulate gene expression, therefore contributing to reducing lipogenesis in differentiated fat cells. Aiming to explore possible concentration-dependent effects we applied two different concentrations of the extract. Interestingly, the manifested effects were stronger in the lower concentration treated cells. It could be assumed that accumulation of polyphenols and probably of other, yet unidentified compounds, might contribute to the above described metabolic effects. At this stage of the investigation we can speculate that the inhibitory effects on lipogenesis are mainly due to the action of polyphenols. Unlike other parts of the plant, the mulberry heartwood contains high amounts of tannins, alkaloids and other specific components which are likely be extracted together with polyphenols. We may suggest that in the higher concentration these compounds may have already insulinlike properties contributing for the diminishing of the inhibitory effect of the extract on the lipogenesis (29). This hypothesis remains to be verified by examining the effect of the extract on different stages of preadipocytes differentiation and glucose uptake. Further examination of the phytochemical composition of the extract may provide more answers to these questions.
In conclusion, our study expands the existing knowledge about the biological effects of mulberry tree. Based on the presented data heartwood ethanol extract from mulberry could be considered a promising source of active compounds with possible beneficial effects for prevention and treatment of obesityrelated metabolic disorders.

\section{REFFERENCES}

1. Barati S, Momtaze H, Azhdary mamoreh M. The effect of hydro-alcoholic extract of Morus nigra leaf on lipids and sugar in serum of diabetic rats. Asian J Biomed Pharm Sci. 2012;2(15):38-40.

2. Beaudoin A. New technique for revealing latent fingerprints on wet, porous surfaces: Oil Red O. J Forensic Identif. 2004;54 (4):413-421.

3. Bordoni A, Di Nunzio M, Danesi F and Biagi PL. Polyunsaturated fatty acids: from diet to binding To PPARs and other nuclear receptors. Genes and Nutrition. 2006;1(2):95-106.

4. Chan $\mathrm{KC}, \mathrm{Ho} \mathrm{HH}$, Lin $\mathrm{MC}, \mathrm{Wu} \mathrm{CH}$, Huang CN, Chang WC, et al. Mulberry water extracts inhibit rabbit atherosclerosis through stimulation of vascular smooth muscle cell apoptosis via activating p53 and regulating both intrinsic and extrinsic pathways. J Agric Food Chem. 2014;62(22):5092-5101.

5. Chan KC, Yang MY, Lin MC, Lee YJ, Chang WC, Wang CJ. Mulberry leaf extract inhibits the development of atherosclerosis in cholesterol- fed rabbits and in cultured aortic vascular smooth muscle cells. J Agric Food Chem. 2013;61(11):2780-2788.

6. Choi BH, Ahn IS, Kim YH, Park JW, Lee SY, Hyun CK, Do MS Berberine reduces the expression of adipogenic enzymes and inflammatory molecules of 3T3-L1 adipocyte. Exp Mol Med. 2006;38:599-605.

7. Cristancho AG, Lazar MA. Forming functional fat: a growing understanding of adipocyte differentiation. Nat Rev Mol Cell Biol. 2011;28:722-34.

8. De Rosso MD, Cancian D, Panighe, A, Vedova AD, Flamini R. Chemical compounds released from five different woods used to make barrels for aging wines and spirits: volatile compounds and polyphenols. Wood Sci Tech. 2009;43:375-385.

9. DeFuria J, Bennett G, Strissel KJ, Perfield JW 2nd, Milbury PE, Greenberg AS, et al.. Dietary blueberry attenuates whole-body insulin resistance in high fat-fed mice by reducing adipocyte death and its inflammatory sequelae. J Nut. 2009;139:1510-1516. 
Effects of mulberry heartwood extract on genes related to lipid metabolism

10. Ejaz A, Wu D, Kwan P, Meydani M,. Curcumin inhibits adipogenesis in 3T3-L1 adipocytes and angiogenesis and obesity in C57/BL mice. J Nutr. 2009;139:919-925.

11. Flamini R, Vedova AD, Cancian D, Panighel A, de Rosso M. GC/MS-positive ion chemical ionization and MS/MS study of volatile benzene compounds in five different woods used in barrel making. J Mass Spectrom. 2007;42:641-646.

12. Habauzit V. and Morand C. Evidence for a protective effect of polyphenols-containing foods on cardiovascular health: an update for clinicians. Ther Adv Chronic Dis. 2012 Mar;3(2):87-106.

13. Hanhoff $T$, Lucke $C$ and Spener F. Insights into binding of fatty acids by fatty acid binding proteins. Molecular and Cellular Biochemistry. 2002;239:45-54.

14. Hsieh YH, Wang SY. Lucidone from Lindera erythrocarpa Makino fruits suppresses adipogenesis in 3T3-L1 cells and attenuates obesity and consequent metabolic disorders in high-fat diet C57BL/6 mice. Phytomedicine. 2013;20(5):394-400.

15. $\mathrm{Hu} X, \mathrm{Wu} J W$, Zhang XD, Zhao QS, Huang JM, Wang HY, Hou AJ. Isoprenylated flavonoids and adipogenesis-promoting constituents from Morus nigra. J Nat Prod. 2011;74(4):816-24.

16. Huang C, Zhang Y, Gong Z, Sheng X, Li Z, Zhang W, Qin Y. Berberine inhibits 3T3-L1 adipocyte differentiation through the PPARgamma pathway. Biochem Bioph Res Com. 2006;348:571-578.

17. Ivanova D, Vankova D, Nashar M. Agrimonia eupatoria tea consumption in relation to markers of inflammation, oxidative status and lipid metabolism in healthy subjects. Arch Physiol Biochem. 2013;119(1):32-7.

18. Jeon T, Hwang SG, Hirai S, Matsui T, Yano H, et al. Red yeast rice extracts suppress adipogenesis by down-regulating adipogenic transcription factors and gene expression in 3T3-L1 cells. Life Sci. 2004;12:3195-3203.

19. Kolehmainen M, Vidal H, Alhava E, Uusitupa MI. Sterol regulatory element binding protein $1 c$ (SREBP-1c) expression in human obesity. Obes Res. 2001;9(11):706-12.

20. Kumar A, Chauhan PK, Bhardwaj VS, Kumar R, Tyagi A. In vitro antioxidant and phytochemical investigations of ethanolic extracts of Viola serpens and Morus nigra. J Chem Pharm Res. 2011;3(4):166-171.
21. Lin J, Della-Fera MA, Baile CA. Green tea polyphenol epigallocatechin gallate inhibits adipogenesis and induces apoptosis in 3T3-L1 adipocytes. Obesity Res. 2005;13: 982-990.

22. Liu LK, Chou FP, Chen YC, Chyau CC, Ho HH, Wang CJ. Effects of mulberry (Morus alba L.) extracts on lipid homeostasis in vitro and in vivo. J Agric Food Chem. 2009;57(16):7605-7611.

23. Liu, LK, Lee HJ, Shih YW, Chyau CC, Wang CJ Mulberry anthocyanin extracts inhibit LDL oxidation and macrophage-derived foam cell formation induced by oxidative LDL. J Food Sci. 2008;73:H113-H121.

24. Livak, K. J., Schmittgen T. D. Analysis of relative gene expression data using real-time quantitative PCR and the 2- $\Delta \Delta \mathrm{C}(\mathrm{t})$ method. Methods 2001;25(4):402-408.

25. Mahmoud M. Y. Natural antioxidants effect of mulberry fruits (Morus nigra and Morus alba L.) on lipids profile and oxidative stress in hypercholestrolemic rats. Pakistan J Nutr. 2013;12:665-672.

26. Pandey KB and Rizvi SI. Plant polyphenols as dietary antioxidants in human health and disease. Oxid Med Cell Longev. 2009;2(5):270-278.

27. Pasheva M, Pavlov D, Tasinov O, Nashar M, Kiselova-Kaneva Y, Ivanova D. Cytoprotective and cytoproliferative effects of ethanol infusions from Morus nigra and Cotinus coggygria heartwood in 3T3-L1 preadipocytes. Scripta Scientifica Medica. 2013;45 Suppl 6:25-28.

28. Pasheva M, Nashar M, Pavlov D, Slavova S, Ivanov D, Ivanova D. Antioxidant capacity of different woods traditionally used for coloring hard alcoholic beverages in Bulgaria. J Sci Technol. 2013;3(1):123-127.

29. Patel DK, Prasad SK, Kumar R, Hemalatha S. An overview on antidiabetic medicinal plants having insulin mimetic property. Asian Pac J Trop Biomed. 2012; 2(4):320-330.

30. Pawlowska AM, Oleszek W, Braca A Quali-quantitative analyses of flavonoids of Morus nigra L. and Morus alba L. (Moraceae) fruits. J Agric Food Chem. 2008;56:3377-3380.

31. Rosen ED, Walkey CJ, Puigserver P, Spiegelman $\mathrm{BM}$ Transcriptional regulation of adipogenesis. Genes Dev. 2000;14:1293-1307.

32. Song Y, Park HJ, Kang SN, Jang SH, Lee SJ, Ko YG, et al. Blueberry peel extracts inhibit adipogenesis in 
3T3-L1 cells and reduce high-fat diet-induced obesity. PLoS One. 2013;8(7):e69925.

33. Venkatesh KR, Chauhan S. Mulberry: Life enhancer. J Med Plants Res. 2008;2(10):271-278.

34. Volpato GT, Calderona IMP, Sinzato S, Campos KE, Rudge MVC, Damasceno DC. Effect of Morus nigra aqueous extract treatment on the maternalfetal outcome, oxidative stress status and lipid profile of streptozotocin-induced diabetic rats. J Ethnopharm. 2011;138(3):691-696.

35. Xie, W., Gu, D., Li, J., Cui, K., Zhang, Y.,. Effects and action mechanisms of berberine and Rhizoma coptidis on gut microbes and obesity in high-fat diet-fed C57BL/6J mice. PLoS ONE 2011;6:e24520.

36. Zheng ZP, Cheng KW, Zhu Q, Wang XC, Lin ZX, Wang M. Tyrosinase inhibitory constituents from the roots of Morus nigra: A structureactivity relationship study. J Agric Food Chem. 2010;58(9):5368-5373. 